\title{
Research on Current Situation of Exchange and Cooperation of Colleges in Fujian and Taiwan under the Supply-side Reform of Higher Education
}

\author{
Jianping Huang \\ Fuzhou University of International Studies and Trade \\ Fuzhou, Fujian, China
}

\begin{abstract}
Economic reform will inevitably promote educational reform and development. The exchange and cooperation of colleges in Fujian and Taiwan conforms to the trend of the times. It is necessary and urgent to carry out supplyside reform of higher education and the exchange and cooperation of colleges in Tujian and Taiwan. This paper researches the development stage, value and trend of exchange and cooperation of colleges in Fujian and Taiwan under the supply-side reform of higher education, in order to provide valuable references for subsequent scholars.
\end{abstract}

Keywords-supply-side reform of higher education; colleges in Fujian and Taiwan; exchange and cooperation

\section{INTRODUCTION}

On Mar.5, 2016, Yuan Guiren, the Minister of Education, addressed on the press conference of the Fourth Session of the 12th NPC, "The transformation and development of colleges in China is the supply-side structural reform of higher education". The research on exchange and cooperation of colleges in Fujian and Taiwan under supply-side reform of higher education provides a new perspective about how to create a good environment for the reform of higher education in China. The research aims at better providing theoretical and practical guidance for successful exchange and cooperation of higher education in Fujian and Taiwan under the guidance of supply-side reform through theoretical research and empirical analysis. The cooperation of colleges Fujian and Taiwan will have a strong radiation effect on economic zone construction in both sides of the Taiwan Straits and the whole nation and play a more significant role in the cooperation in running schools of Fujian and Taiwan in the future. It will also make tremendous contribution to maintain the unification of Chinese nation.

\section{DEVELOPMENT STAGES OF EXCHANGE AND COOPERATION OF COLLEGES IN FUJIAN AND TAIWAN}

On Jul.14, 1987, Chiang Ching-kuo, the president of "Republic of China", signed an Executive Order and declared martial law ended from zero hour on Jul. 15, allowing Taiwan

Fund project: Planning topic of the Ministry of Education subsidized by national educational science planning unit: Research on Exchange and Cooperation of Colleges in Fujian and Taiwan under the Supply-side Reform of Higher Education (FIB160490). people to go home to visit their families on the mainland. Afterwards, the Taiwan authorities approve principals of public universities and civil servants to carry out cultural and educational activities. Professionals on the mainland can also give lectures in Taiwan. The exchange and cooperation of higher education between Taiwan and mainland begins. In the recent thirty years, the exchange and cooperation of colleges in Fujian and Taiwan improves continuously and consists of the following development stages:

\section{A. Understanding Stage (1987 to 1992)}

After the declaration of the end of martial law in July 1987, the mainland issues the stipulation on educational exchange with Taiwan and allows exchanges visits and seminar between Taiwan and mainland. In November 1988, Taiwan issued the Principle of Review of Elite Personnel of the Mainland, Overseas Personage and Students in Visiting Taiwan, allowing professionals of the mainland to visit Taiwan. The mutual understanding and exchange of people in Taiwan and mainland begins. In 1991, Li Denghui in Taiwan proposed to "list the cultural exchange of Taiwan and mainland as the first priority project", including the exchange of scholars and students between Taiwan and mainland. In April 1990, leaders of a private university of Taiwan namely Tamkang University paid a visit to the original Lujiang Vocational College and opened a new page of higher education in Taiwan and Fujian. In February 1992, together with 17 people, Dar-Chin Rau, the director of industrial education research institute and the industrial education department of National Taiwan Normal University visited the Original Fujian Zhonghua Vocational University. In 1992, Chen Qifeng proposed the prospect of educational exchange and cooperation between Fujian and Taiwan is under the influence of politics, economy and geoculture of Taiwan and mainland. The exchange at this stage is confined to non-governmental organization and individuals with small scope and shallow degree because of the limitations from Taiwan. It is in the understanding stage.

\section{B. Interactive Stage (1993 to 2000)}

In February 1993, after being appointed as "the Minister of Education", Guo Weifan issued and implemented Permission for Professionals of the Mainland to Engage in Professional Activities in Taiwan. In 1994, Taiwan authorities published the 
Explanation of Relations across the Taiwan Straits and accepted the "One-China" policy. During this period, the exchanges of colleges between Fujian and Taiwan are frequent. During 1995 and 1996, educators of Taiwan visited our province and exchanged with us. In 1997, Chen Qian thought with the continuous development of exchange between both sides of the Taiwan Straits, Taiwan compatriots want to roundly understand the education on mainland while donating money for education with enthusiasm. In January 1998, the first session of educational seminar participated by colleges students on both sides of the Taiwan Straits was held in Xiamen University. Scholars of Taiwan and mainland made an in-depth discussion on "Development Trend of College Education in the 21st Century" and "Funds of College Education". In this stage, the exchange of higher education between Fujian and Taiwan had been strengthened and initially became two-way and diversified. Fujian and Taiwan deepen understanding, increase academic exchange and research and build a bridge for further exchange and cooperation of higher education in Taiwan and mainland.

\section{In-Depth Exchange Stage (2001 till Now)}

The governing party of Taiwan changed in 2000. Although the Taiwan authorities hold negative attitudes toward the educational exchange of Taiwan and mainland, it fails to stop the enthusiasm of people in Taiwan and mainland in exchange. Huang Xinxian [1] (2001) analyzed the historical reasons of educational integration between Fujian and Taiwan. In Apr. 29, 2005, Hu Jintao, the General Secretary of the Communist Party of China shook hands with Lien Chan, chairman of Nationalist Party of China, in the Great Hall of the People. It is the first time for leaders of the two parties to shake hands after the 60th anniversary of the founding of the People's Republic of China. Hong Jie (2006) proposed according to the statistics, nearly 4,000 students from Taiwan are admitted in classes of bachelor degree or above in Fujian province. In 2005, the Ministry of Education approved Xiamen University, Fujian University of Traditional Chinese Medicine, Fujian Normal University, Fuzhou University, Fujian Medical University, Fujian Agriculture and Forestry University, Huaqiao University and Yang-En University to enroll Taiwan students separately. In December 2006, the first session forum of principals in universities of both sides of the Taiwan Straits was held in Fuzhou. Principals and representatives of 57 universities including more than 20 universities of Taiwan attended the forum that builds the exchange platform for principals of universities in Taiwan and mainland to promote the exchange of higher education in Taiwan and mainland. In December 2007, the first session forum for principals of vocational colleges in both sides of the Taiwan Straits was held in Fuzhou. Twelve pairs of colleges of Taiwan and mainland during the forum signed the letter of intent for cooperation and exchange. The Kuo Min Tang returned to power in 2008. The relations across the Taiwan Straits enter new stage of benign development. Lin Dong (2008) proposed the economic zone construction on both sides of the Taiwan Straits proceeds energetically. The investment of Taiwan businessmen increases continuously. It urgently needs a large number of front line talents of technical application and high skills to promote the exchange of vocation education in
Taiwan and mainland and serve industrial connection of Fujian and Taiwan as well as promote the joint development of educational enterprises on both sides. In September 2008, the joint training center of Yung Ta Institute of Technology and Commerce and Fujian Industrial School established and became the first joint training center of Fujian and Taiwan. In April 2009, the "2009 Exhibition of Higher Vocational Education in Both Sides of the Taiwan Straits" was held in Xiamen. More than ten universities in both sides of the Taiwan Straits signed twelve projects of educational exchange and cooperation. It is a substantial exploration for Taiwan and mainland. Since the autumn of 2009, universities in Fujian like Fujian Vocational Technical Institute of International Studies and Trade have carried out the new cooperation strategy in educational field of Fujian and Taiwan, the "UniversityUniversity-Enterprise" pattern. The "University-UniversityEnterprise" refers to the cooperative relationship among "universities in mainland", "universities in Taiwan" and "Taiwan-funded enterprise", in order to bring in dominant specialties of Taiwan to fill in gas of badly-needed talents training in Fujian. In 2012, the Regulations of Fujian Province on the Promotion of Vocational Education Cooperation between Fujian and Taiwan was listed as the research project of legislation plan by the Standing Committee of the National People's Congress of Fujian Province. It put the formulation of the Promotion of Vocational Education Cooperation between Fujian and Taiwan on the agenda, in order to bring the unique superiority of Fujian province in exchange with Taiwan into full play and strive for new breakthrough and new creation on the principle and opportunity of early and pilot implementation. Zhang Zhuoqi and Yang Aige [2] (2013) thought the sharing of educational resources can effectively gather teaching resources of Fujian and Taiwan. Guo Qingying [3] (2015) analyzed current situation, problems and countermeasures of educational exchange and cooperation between Taiwan and mainland, in order to actively promote the cooperation of higher education in Taiwan and mainland. On Sept. 25, 2015, the Standing Committee of the People's Congress of Fujian province issued the Regulations of Fujian Province on the Promotion of Vocational Education Cooperation between Fujian and Taiwan and implemented it on December 1 . Wu Xiaojian [4] (2015) proposed to actively build the platform for sharing of superior resources on both sides of the Taiwan Straits and strengthen the construction of teaching body in colleges of Fujian and Taiwan and cooperation of scientific research. In general, in this stage, the educational exchange of colleges in Fujian and Taiwan is more active than ever before. The governments promote and encourage early and pilot implementation of education in Taiwan and mainland. The exchange and cooperation deepens and the scale enlarges. Various exchange platforms are normal increasingly. Substantial cooperation is promoted through specific projects.

The research on stages of exchange and cooperation of colleges in Fujian and Taiwan provides abundant references for the research on "exchange and cooperation of colleges in Fujian and Taiwan under supply-side reform of higher education and lays a solid foundation for in-depth and systematically research on this subject. 


\section{RESEARCH VALUE OF EXCHANGE AND COOPERATION OF COLLEGES IN FUJIAN AND TAIWAN}

\section{A. Deepen the Supply-Side Reform of Higher Education}

When the economic and social development makes great progress, we find the higher education structure of China is unreasonable in economic upgrade and industrial transformation. Most schools train theoretical and academic talents instead of technical talents. The homogenization phenomenon is severe. The research on exchange and cooperation of colleges in Fujian and Taiwan is conducive for the supply-side reform of higher education to operate from a strategically advantageous position and directly concerns the structural adjustment of colleges, the prospect of national education.

\section{B. Enrich Exchange and Cooperation of Colleges in Fujian and Taiwan}

The research on exchange and cooperation of colleges in Fujian and Taiwan means systematically researching the exchange and cooperation relationship of colleges in Fujian and Taiwan under supply-side reform of higher education. It explores to integrate the supply-side reform of higher education in the exchange of colleges in Fujian and Taiwan, further develops the theoretical research and enriches the research on supply-side reform of higher education.

\section{Provide Practice Guidance in Carrying forward Supply- Side Reform of Higher Education}

Higher education has achieved obvious development in recent years. However, the long-term idea of demand side reform leads to problems in structure, quality and efficiency of higher education. Therefore, the research on exchange and cooperation of colleges in Fujian and Taiwan provides significant practice guidance in carrying forward the supplyside reform of higher education.

\section{Provide Guidance in Training Applied and Innovative Talents and Solving Supply-Side Structural Contradictions of Education}

Economic reform will inevitably drive educational reform. Since the reform and opening-up, the rapid economic development arouses people's demands for higher education. Higher education trains more theoretical and academic talents. At present, the talent training mode fails to comply with the requirement of economic upgrade and industrial transformation for applied and innovative talents. Colleges in Taiwan have mature experience in training applied and innovative talents. The relations of colleges between Fujian and Taiwan are increasingly close. Therefore, it is distinctly important to strengthen the research on the exchange and cooperation of colleges in Fujian and Taiwan under supplyside reform of high education.

\section{RESEARCH TRENDS OF EXCHANGE AND COOPERATION OF COLLEGES BETWEEN FUJIAN AND TAIWAN}

\section{A. Research the Macro-Background of Exchange and Cooperation of Colleges between Fujian and Taiwan}

On the basis of higher education development in Fujian and Taiwan, we can clearly seek the significance and strategic direction and propose idea of exchange and cooperation of colleges in Fujian and Taiwan under supply-side reform of higher education through historical line of adjustment of higher education in Fujian and Taiwan. Requirements of research on exchange and cooperation of colleges in Fujian and Taiwan under supply-side reform of higher education can be raised through research on the exchange relationship.

\section{B. Investigate the Current Situation of Exchange and Cooperation of Colleges in Fujian and Taiwan under the Supply-Side Reform of Higher Education}

The research on exchange and cooperation of colleges in Fujian and Taiwan can proceed with the investigation on current situation. We can draw some samples in Fujian and Taiwan and research through interview, questionnaire and statistic analysis, including: current situation and requirement of exchange and cooperation in Fujian and Taiwan, the cognition and expectation of students and society for it and the macro and micro factors that influence it.

\section{Research the Value of Exchange and Cooperation of Colleges in Fujian and Taiwan under Supply-Side Reform of Higher Education}

We can guide the research of exchange of colleges in Fujian and Taiwan under supply-side reform of higher education through analyzing the current situation of exchange and cooperation of colleges in Fujian and Taiwan and basing on the internal and external environment of supply-side reform of higher education. It mainly manifests: the goals, patterns and specifications of cooperation in talent training of higher education in Fujian and Taiwan change from "theoretical and academic talents" to "technical and skill-oriented talents"; the exchange and cooperation of scientific research in higher education of Fujian and Taiwan changes from "longitudinal extension" to "transverse span"; the social service of higher education in Fujian and Taiwan changes from "being in name only" to "being worthy of the name".

\section{Research the Cases of Exchange and Cooperation of Colleges in Fujian and Taiwan under Supply-Side Reform of Higher Education}

We can research from practical level through investigation on cases of colleges in Fujian and Taiwan. On the basis of extensive investigation, according to cases of exchange and cooperation of colleges in Fujian and Taiwan in recent years, deeply analyze the direction of cooperation, improve successful experience in cooperation of colleges in Fujian and Taiwan in running schools, and further verify the necessity and feasibility of research on exchange and cooperation of colleges in Fujian and Taiwan under supply-side reform of higher education. 
E. Research the Strategy of Exchange and Cooperation among Colleges in Fujian and Taiwan under the Background of Supply-Side Reform of Higher Education

In contents and forms, we can realize exchange and cooperation in school-running idea and practice of colleges in Fujian and Taiwan and continuously enrich the contents and forms of social service of colleges in practice. In mechanism and strategy, realize system innovation of exchange and cooperation, including: The pursuit for development is the internal driving power of exchange and cooperation of colleges in Fujian and Taiwan; the structural contradiction that the structure of higher education fails to comply with industrial structure is the external driving power; government participation is the support strength; medium organization is indispensable assisting force.

\section{CONCLUSION}

To sum up, it proposes new research perspective for exchange and cooperation of colleges in Fujian and Taiwan under the supply-side reform of higher education. According to the analysis on understanding stage, interactive stage and indepth stage of exchange and cooperation of colleges in Fujian and Taiwan, it provides guidance for deepening and carrying forward supply-side reform of higher education as well as enriching cooperation of colleges in Fujian and Taiwan and solving the supply-side structural contradiction of education. Besides, this paper predicts the macro-background, investigates the current situation, and researches the value and strategy of cooperation of colleges between Fujian and Taiwan, in order to promote the research on current situation of exchange and cooperation of colleges in Fujian and Taiwan.

\section{REFERENCES}

[1] Huang Xinxian. Historical Reasons of Educational Integration between Fujian and Taiwan, Educational Criticism [J], 2001 (04): 60-63

[2] Zhang Zhuoqi, Yang Aige. Construction of Platform for Sharing of Educational Teaching Resources in Both Sides of the Taiwan Straits [J], Journal of Inner Mongolia Radio TV University, 2013 (05): 106-108

[3] Guo Qingying. Comparison and Reference of Current Situation of Higher Education in Fujian and Taiwan [J], Journal of Anhui Vocational and Technical College, 2015 (04): 60-63

[4] Wu Xiaojian. Research on Countermeasures of Platform Construction of Vocational Education Base in Fujian and Taiwan [J], Journal of Xiamen City Vocational College, 2015 (02): 1-4 